\title{
"Anishinaabe time": temporalities and impact assessment in pipeline reviews
}

\author{
Sâkihitowin Awâsis ${ }^{1}$ \\ Western University, Canada
}

\begin{abstract}
Indigenous ways of living that embrace multiple temporalities have been largely supplanted by a single, linear colonial temporality. Drawing on theoretical insights from Indigenous geographies and political ecology, this article considers how pipeline reviews come into being through contested temporalities and how dominant modes of time dispossess Indigenous peoples of self-determination in energy decision-making. In particular, Anishinaabe clan governance - a form of kinship that provides both social identity and function based on relations to animal nations - is undermined in colonial decision-making processes. Through analysis of documents from Canada's National Energy Board and interviews with Anishinaabe pipeline opponents, I explore tensions between Anishinaabe and settler temporalities reflected in the 2012-2017 Line 9 pipeline dispute in the Great Lakes region. These include divergent understandings of periodicities, timeframes, kinship relations, and the role of nonhuman temporalities in decision-making. Colonial temporal modes that have been imposed on Indigenous communities foreshorten timescales, depoliticize kinship relations, and discount nonhumans in decision-making - resulting in narrower and more short-sighted project reviews than Anishinaabe temporalities would support. I argue that the rich concepts of kinship, queerness, continuity, and prophecy embedded in Anishinaabe temporalities can inform strategies for decolonizing energy review processes and open possibilities for Indigenous self-determination in energy decision-making.
\end{abstract}

Keywords: Anishinaabe studies, Two-Spirit, Indigenous geographies, temporalities, Indigenous knowledge, energy governance, pipeline, National Energy Board

\section{Résumé}

Les modes de vie autochtones qui embrassent de multiples temporalités ont été largement supplantés par une temporalité coloniale linéaire unique. S'appuyant sur les connaissances théoriques des géographies autochtones et de l'écologie politique, cet article examine comment les " revues de pipeline " naissent à travers des temporalités contestées et comment les modes dominants du temps dépossèdent les peuples autochtones de l'autodétermination, dans la prise de décision énergétique. En particulier, la gouvernance du clan Anishinaabe - une forme de parenté qui fournit à la fois une identité sociale et une fonction basée sur des relations avec les nations animales - est minée par les processus de prise de décision coloniaux. À travers l'analyse de documents de l'Office national de l'énergie du Canada et des entrevues avec des opposants au pipeline Anishinaabe, j'explore les tensions entre les temporalités des Anishinaabe et des colons reflétées dans le différend sur la canalisation 9 de 2012-2017 dans la région des Grands Lacs. Celles-ci incluent des compréhensions divergentes des périodicités, des délais, des relations de parenté et du rôle des temporalités non humaines dans la prise de décision. Les modes temporels coloniaux qui ont été imposés aux communautés autochtones raccourcissent les échelles de temps, dépolitisent les relations de parenté et écartent les non-humains dans la prise de décision - ce qui se traduit par des revues de projets plus étroites et plus myopes que les temporalités Anishinaabe ne le soutiendraient. Je soutiens que les riches concepts de parenté, de queerness, de continuité et de prophétie intégrés dans les temporalités Anishinaabe peuvent éclairer les

\footnotetext{
${ }^{1}$ Sâkihitowin Awâsis, PhD Candidate, Western University, Canada. Email: CDakin2 "at" uwo.ca. Acknowledgements: I am deeply grateful for Dr. Carol Hunsberger's insight and encouragement while developing ideas that are central to this article, and referees. This research is supported in part by funding from the Social Sciences and Humanities Research Council of Canada. This is the first article in Ashley Fent and Erik Kojola (eds.). 2020. "Political ecologies of time and temporality in resource extraction", Special Section of the Journal of Political Ecology 27: 819-938.
} 
stratégies de décolonisation des processus d'examen énergétique et ouvrir des possibilités d'autodétermination autochtone dans la prise de décision énergétique.

Mots clés: études Anishinaabe, bispirituelles, géographies autochtones, temporalités, connaissances autochtones, gouvernance énergétique, pipeline, Office national de l'énergie

\section{Resumen}

Los modos de vida indígenas que adoptan múltiples temporalidades han sido ampliamente suplantado por una única temporalidad lineal colonial. Con base en las nociones teóricas de geografías indígenas y ecología política, este artículo considera cómo las evaluaciones de los oleoductos son elaboradas a través de temporalidades cuestionadas, y cómo, las formas dominantes de tiempo, despojan a la población indígena de su autodeterminación en la toma de decisiones sobre energía. En particular, la gobernanza del clan Anishinaabe - una forma de parentesco que provee identidad social y función con base en la relación con naciones animales- es debilitada en los procesos coloniales de tomas de decisiones. A través del análisis de documentos de Consejo Nacional de Energía de Canadá, así como entrevistas con opositores Anishinaabe, exploro las tensiones entre Anishinaabe y las temporalidades coloniales reflejadas en la disputa del oleoducto 2012-2017 Línea 9, en la región de los Grandes Lagos. Estas incluyen las interpretaciones divergentes de periodicidades, lapsos, relaciones de parentesco, y el papel de temporalidades no humanas en la toma de decisiones. Las formas temporales coloniales que han sido impuestas en comunidades indígenas acortan lapsos, despolitizan relaciones de parentesco y descartan no humanos en las tomas de decisiones - lo que resulta en una revisión de proyectos más estrecha y de corta visión que las temporalidades Anishinaabe pueden sostener. Discuto que los complejos conceptos de parentesco, "queerness", continuidad, y profecía integrados en las temporalidades Anishinaabe puede orientar sobre estrategias para descolonizar procesos de revisión energética, así como abrir posibilidades a la autodeterminación indígena en tomas de decisión sobre temas de energía.

Palabras clave: estudios Anishinaabe, dos espíritus, geografías indígenas, temporalidades, conocimiento local, gobernanza energética, oleoductos, Consejo Nacional de Energía

\section{Introduction}

Anishinaabe $A k i^{2}$, the homeland of the Anishinaabeg confederacy, stretches from the eastern woodlands of the Great Lakes to the prairie grasslands in the west, including territories shared with neighboring Indigenous and non-Indigenous nations. This rich landscape is the foundation of who I am as a Michif Anishinaabe niizh manidoo (two-spirit) of the Waabizheshi Dodem (Pine Marten Clan). I am from Wemitigoj Sibi (French River) and live along Deshkan Ziibiing (Antler River). At the time of writing, it is Namebini Giizis, literally Sucker Fish Moon in the Anishinaabemowin language. This time of year, the sucker fish are migrating up rivers and streams to find a good place to lay their eggs. Yet if I were to visit another Anishinaabe community - Nohkomis (my grandmother) in Sagkeeng, for instance - they may refer to the same period as Makwa Giizis (Bear Moon), observing the time when bears begin to emerge from hibernation and move things around in their dens (Benton-Banai 2008).

I begin with this short anecdote to emphasize several key ideas that are integral to decolonizing how time is understood in pipeline reviews (impact assessments). First, knowledge encoded in Anishinaabemowin, the Anishinaabe language, provides meaning that cannot be expressed in English (Corbiere 2013). If I had translated Namebini Giizis directly to the English name, February, the connection to the suckers' spawning time would be lost. Second, Anishinaabe peoples, like many Indigenous nations globally, embrace multiple temporalities while centering Indigenous ways of knowing (Davidson-Hunt and Berkes 2003; Igreja 2012; Iparraguirre 2017; Rifkin 2017). Anishinaabe gkendaasowin (knowledge) is land-based and embodied in individuals, families, communities, and nations that enact a multiplicity of temporal modes. Nohkomis and I can refer to different moons at the same time, depending on where we are. Third, Indigenous temporalities can be understood as enmeshed with the land, a set of "relationships of things to each other" (Deloria 2001: 23). The land provides a contextualizing background for governance practices and self-determination (Powell 2015; Rifkin 2017). 
Indigenous spaces, places, and environments animate temporal processes. I use the terms 'temporal' and 'time' interchangeably with 'spatiotemporal' and 'space-time' throughout this article to denote how temporalities exist only in relation to material landscapes. There are no abstract concepts of "time" in Anishinaabemowin, as "time" always carries greater specificity: aabiding (at one time), azhigwa (at this time), or gomaapii (for some time) (Richotte 2013). Anishinaabe temporal multiplicity is learned from the land and inherent in the natural flow of time - the creation of the multiverse, the change of the seasons, the earth's solar rotation, and the lunar cycle.

On the land, there is nothing inherent in the flow of time to suggest that there is such things as a 7-day work week, 24-hour clock time, or the Gregorian calendar. These temporal concepts fit into larger Western assumptions about a single, linear temporality, comprised of shared present and homogeneous movement along a singular axis, through empty time (Rifkin 2017). Capitalism is constituted by this spatiotemporality; clock time's quantifiability into definitive periods that can be used to measure workers' remuneration is central to the capitalist mode of operation (Castree 2009). Canadian institutions reflect the global reach of this normative temporal structure that emphasizes notions of universality, simultaneity, progress, punctuality, productivity, acceleration, and instantaneousness (Huebener 2015). Colonial institutions, such as Canada's National Energy Board, use a narrow concept of decision-making as a successive, universal line of development, while Anishinaabe dodemiwan (clan governance) exceeds the notion of universal time that structures dominant pipeline reviews. The colonial matrix of institutional temporal principles undermines Indigenous governance and reinforces colonial power relations in four ways. First, it assumes one temporality is superior to or more legitimate than all others. Second, it provides settler authorities with the ability to define temporal starting and ending points, as well as the duration and context of social processes. Third, it prioritizes certain timeframes (the present and shorter durations) over others. Fourth, it imposes constraints in terms of gender, age, race, class, sexuality, and nationality, on temporal understandings (Huebener 2015). Although settler time seems all-encompassing, it is both highly limited and limiting.

The imposition of dominant measurements of time on diverse temporal understandings limits Indigenous governance to modes that align with the settler spatiotemporality. Institutional time has come to orient colonial modes of governance as well as provide the background through which Indigenous nationhood is made intelligible to colonial authorities (Rifkin 2017). In colonial decision-making, Indigenous governance is flattened (decoupled from social, political, ecological, and economic claims), institutionalized (inserted into the present on non-Native terms), and frozen (cast to the past) (Borrows 2012; Coulthard 2014; Ogden 2009). In pipeline reviews, colonial recognition of Indigenous governance occurs in ways that invalidate Indigenous self-determination and flatten Indigenous governance by excluding Indigenous political and economic systems (Coulthard 2014; Dokis 2015; McCreary and Milligan 2013). Against this institutional background, Indigenous governance is treated as difference within colonial nations, and Indigenous lands are required to remain open to capitalist development. In the late $19^{\text {th }}$ century, Indian legislation, such as the Indian Act (1876) in Canada and Indian policy (1870s-1880s) in the US, homogenized Indigenous nations into institutional forms of governance, delineated Indian status on non-Native terms, facilitated large-scale dispossession, and fragmented Indigenous confederacies into reserve boundaries (Irwin 1997; Simpson 2017). In Canada, Indigenous rights are still frozen when colonial authorities demand that Indigenous legal systems, land title, and land-based activities demonstrate linear continuity with practices that were happening at the time of contact to be formally recognized through section 35 of the 1982 Constitution Act (Borrows 2002). The focus on pre-contact practices severely restricts Indigenous governance, anchoring Indigenous peoples to the past (Huebener 2015; Rifkin 2017). Indigenous self-determination in energy decision-making demands a more expansive understanding of space-time that does not treat settler institutions as the baseline for Indigenous governance. Temporal justice provides a guiding framework for this decolonial project.

This article applies ideas from temporal justice literature and concepts embedded in Anishinaabe spatio-temporalities (kinship, queerness, continuity, and prophecy) to provide for a more expansive understanding of impact assessments in pipeline reviews. Focusing on the Line 9 pipeline dispute and the National Energy Board (NEB) review, I ask: in what ways are Anishinaabe temporalities divergent from and impacted by settler temporal modes, and how can these insights be applied to pipeline impact assessments? To answer these questions, I take a decolonizing approach to document analysis and in-depth qualitative 
interviews $(\mathrm{n}=26)$ to trace temporalities reflected by Anishinaabe community members who opposed the Line 9 reversal. Anishinaabe temporalities can inform strategies for decolonizing energy project review processes and open possibilities for Indigenous self-determination in energy decision-making. My analysis finds that divergent temporal understandings include:

1. periodicities - moons, seasons, ceremonies vs. election cycles, court sessions, the financial year;

2. timeframes - seven generations before and after vs. the current generation;

3. kinship relations - land-based political systems vs. hetero-nuclear cultural identities, and

4. the role of nonhuman temporalities in decision-making - centered vs. dismissed.

Anishinaabe time can be understood here as a legitimate and self-sufficient temporal understanding, not in opposition to settler time. Yet Anishinaabe temporalities do not indicate insulation from colonial violence. Although Indigenous temporalities are irreducible to a mere antithesis of settler institutional time, Indigenous and settler temporalities exist alongside each other with imbalanced power relations. The embodied concepts I explore are aspirational, in that they provoke us all to adjust our everyday conceptions of time to challenge dominant temporal assumptions.

\section{Gkendaasowin (knowledge)}

In Mikinaak Minis (Turtle Island or North America) the settler-colonial relation is characterized by interrelated economic, gender, racial, and state powers that comprise hierarchical social structures and continue to facilitate the dispossession of Indigenous peoples of our lands, knowledge systems, and selfdetermination (Coulthard 2014). The primary motivations of settler colonialism are to accumulate wealth and territorial control. Oil and gas pipeline systems imposed on Mikinaak Minis are an extension of settler colonialism, with extensive social and ecological impacts that continue to pose risks to the health of interrelated human and nonhuman communities. There have been ongoing Indigenous-led protests, legal challenges, and arrests in opposition to pipeline projects since the Idle No More movement began in winter 2012. Nation-specific, land-based knowledge systems are becoming increasingly central to Indigenous pipeline resistance movements' legal challenges and direct actions. For example, the Unist'ot'en and Gidimt'en clans of the Wet'suwet'en nation are challenging seven proposed oil and gas pipeline projects across Wet'suwet'en Yintah (territory in northern British Columbia) by establishing healing camps and checkpoints, as well as pursuing legal action in both colonial courts and their original governance structures (Bowles and Veltmeyer 2014; Unist'ot'en Camp 2017).

\section{Temporal justice}

Situated alongside social and environmental justice in ongoing debates about what defines a just society, theories of temporal justice are concerned with the differential impacts that policies and practices have on temporal self-determination, which is communities' capabilities to choose their own temporal modes. For instance, Goodin (2009) demonstrates how temporal injustice is discernable when some groups of people have greater amounts of discretionary time than others. Huebener (2015) expands upon this definition to suggest that temporal justice more broadly pertains to any form of equity at stake in the diverse ways time functions as a tool of power. Temporal justice literature has evolved to focus on issues relating to Indigenous rights, discourse and framing, and how temporal modes can be used as a tool of colonial power (Kowal 2015; Love and Tilley 2013; Weir 2013).

Another foundational element of temporal justice is Indigenous sovereignty. For Rifkin (2017), temporal sovereignty provides a means of pluralizing temporalities to help facilitate expressions of Indigenous self-determination that do not depend on inclusion within institutional modes of time. From an Anishinaabe perspective, dodemiwan (clan governance) does not rely on institutionality to maintain structure (Dumont 2015). Dodemiwan is spatiotemporal in the sense that it governs intergenerational knowledge 
transmission and is situated in direct relationship with the land. Anishinaabe society is based on responsibilities and intimate connections to animal nations (and, less commonly, plant and other nonhuman nations) that provide social identity and function. When fully intact, the kinship network was a territorial, consensus-based decision-making structure (Giniwgiizhig 2013; Simpson 2017).

Anishinaabe Chi Inaakonigewin (Natural law) provides context for dodemiwan. Chi Inaakonigewin is encoded in ceremonies, songs, and stories, observed in the environment, and embedded in continual processes of reciprocal relationship-building with human and nonhuman kin (Borrows 2002, 2017; Dumont 2015). I will demonstrate that temporal justice demands that Anishinaabe peoples have the capability to make decisions that could impact the land in contexts and through processes that adhere to Chi Inaakonigewin. The resurgence of Indigenous decision-making processes is both an element of, and a condition for, temporal justice that simultaneously challenges the legitimacy of colonial decision-making institutions, misrecognition, and the disproportionate distribution of power. In the section that follows, I discuss how Indigenous spatiotemporalities relate to recent debates in Indigenous geographies and political ecology.

\section{Indigenous geographies and political ecology?}

Political ecologists look at everyday practices, how they emerge from forms of social organization, and how the associated forms of knowledge detail specific relationships between political, legal, and economic factors that relate to ecological issues. Political ecology works to absorb components of particular fields into its research to improve the breadth of its explanatory capacity, and this has led to a proliferation of what can be called "and" political ecologies: land change science and political ecology, sustainability science and political ecology, and environmental health and political ecology (Robbins 2015). The engaged field is mimicked and critiqued, but it also mobilizes categories of political ecology, such as race, class, gender, discourse, and colonial power. Robbins (2015) calls this process "infection by critique"; political ecology coevolves with the fields with which it critically engages. Political ecology can be considered vital to recent progress in Indigenous geographies, refocusing attention on external processes that create the context for resource extraction and exploitation, as well as providing theoretical tools to help address contemporary challenges for Indigenous governance (Carroll 2014). At stake is the extent to which political ecology is informed by Indigenous geographies. This section synthesizes and expands upon current debates on the compatibility of Indigenous knowledge and political ecology in relation to multi-temporalities in pipeline reviews.

Indigenous geographies are part of a broader movement within Indigenous and academic communities over the last twenty years to critique and re-envision the fundamental concepts and practices of research (Wilson 2008; Larsen and Johnson 2012). Indigenous geographies center Indigenous knowledge systems and knowledge holders in geographic inquiry; the research goals, questions, and practices reflect the localized knowledge and needs of Indigenous communities (Coombes et al. 2014; Frantz and Howitt 2012; Louis 2007). The relationality of place is a persistent theme. Place-based ethics serve as a foundation for critiques of colonial power relations (Coombes et al. 2012; Coulthard 2014). Place-based politics rooted in Indigenous conceptions of responsibility and autonomy form a basis for alliance-building (with both humans and nonhumans) (Coombes et al. 2013; Haluza-DeLay and Carter 2014). Relational conceptions of place also emphasize the distinct nature of Indigenous ontologies and their potential for transforming how knowledge is generated (Coombes et al. 2013; Johnson et al. 2016). Indigenous experiences of "being-together-in-place" (Johnson et al. 2016) or "being-on-the-land" (Larsen and Johnson 2012) reframe struggles for selfdetermination in both relational and decolonial terms (Coombes et al. 2013).

Political ecology complements Indigenous geographies by promoting attention to the agency of the land in a way that rejects a nature/culture binary and is consistent with Indigenous understandings of environmental sentience (Coombes et al. 2012). Both Indigenous geographies and political ecology are praxis-based and informed by an engagement with activism, often in close collaboration with activists themselves (Bebbington 2004; Daigle 2016; Heyen and Van Sant 2015; Johnson et al. 2017; Pine 2016; Sundberg 2003). There is a clear ethical dimension in both these bodies of work, as well as movement away 
from conflating Indigenous with local (Castree 2004). Indigenous practices are neither locally-bound nor easily transferable to the transnational (Coombes et al. 2012).

In both fields, postcolonial studies examine how colonialism has worked through social, cultural, and political institutions and identities (Yeh and Bryan 2015). Yet this attention has not gone far enough, often reinforcing inequalities by attempting to contain Indigeneity within broader postcolonial discourses (Coombes et al. 2013). By focusing on colonial norms and power perpetuated within the state, Indigenous peoples are cast as inherent victims (Larsen and Johnson 2012). Postcolonial approaches to research can center Indigenous communities while simultaneously and unintentionally contributing to Indigenous assimilation. This stresses the importance of locating Indigenous research in the "(de)colonial present" (Larsen and Johnson 2012). A retrospective gaze on the ongoing limitations on Indigenous peoples' capability to transcend colonial power relations should be balanced with aspirational cases of political resurgence (Coombes et al. 2013). Indigenous geographies and political ecology direct attention to ontological difference and the more-than-white/human forces that shape Indigenous ways of living (Country et al. 2013; Panelli 2008). The question then becomes, how can political ecology take a decolonizing approach to engaging with the agency of the land? This could support, for example, committed engagement with movements of people who are concerned with offending land-based deities (Nelson 2013; Yeh and Bryan 2015). Yet there remain serious unresolved concerns about incorporating Indigenous knowledge into political ecology analysis.

All dominant paradigms (positivism, post-positivism, constructivism, and critical theory) treat knowledge as individual in nature; political ecology, grounded in critical theory, is no different (Wilson 2008). Political ecologists risk making the multiculturalist assumption that we exist in a world with many different cultural understandings of a single nature, while Indigenous knowledge systems entail multinaturalist ontologies that recognize a multiplicity of truths (Coombes et al. 2012; Wilson 2008). This issue stems from a failure to account for ontological diversity and from assumptions about Indigenous peoples suffering an "ontological flaw", occupying a subontological position in both scholarship and everyday life (Ciccariello-Maher 2017; Sundberg 2014). Political ecology can easily slide into universal concepts that fail to take Indigenous lands or cultures seriously and reduce both to the impacts of external structures. The subjugated agency of nonhumans is a persistent problem, when the concepts of agency and personhood are modified and limited when applied to nonhumans (Burow et al. 2018; Middleton 2015). Similarly, Indigenous critiques of sovereignty are often based on the inability of the concept of sovereignty to account for nonhuman worlds (Carroll 2014; Simpson 2017). While Indigenous peoples' emphasis on collective place attachment has been a successful response to dispossession, it can simultaneously affirm structural inequality and obscure everyday forms of dispossession under capitalism (Yeh and Bryan 2015). For these reasons, Coombes et al. (2012) are hesitant about an alignment between Indigenous geographies and political ecology.

From an Indigenous perspective, another critique of political ecology is that politics are overly simplified. Political ecology can undermine state territorial claims, but it does not tell Indigenous peoples anything we do not already know (Robbins 2015). In part because of the objectivist mode of measurement, political ecology cannot, on its own, generate the creativity and reflection necessary to decolonize Indigenous lands and knowledge. Indeed, the very analytical approaches employed by political ecologists often objectify the world, and insistence on such forms of explanation can move Indigenous peoples and geographies further away from self-determination and the possibility of more just outcomes (ibid). As a result, Indigenous governance scholars have approached Indigenous political ecology in ways that directly challenge colonial logics, such as the commodification of land, property ownership, and epistemological hierarchies embedded in colonial law (McCreary and Milligan 2013; Middleton 2015).

To more fully engage with decolonial possibilities, Middleton (2015) suggests re-asserting local names for places, local stories, and local responsibilities to those places. Indigenous political ecology centers placespecific Indigenous ways of knowing to understand intersecting ecological, social, political, and economic factors. Articulating an Indigenous political ecology aims to change the context of knowledge generation and sharing, and, thereby, the questions that inform impact assessments. Framing questions in terms of Indigenous creation narratives, for instance, will differ significantly from assessment processes based on Western temporal forms. Indigenous multi-temporalities are useful for political ecologists because they open possibilities for engaging with diverse ontologies that expand the conceptual terrain across which Indigenous 
knowledge systems are engaged. In brief, this work can seek to make Indigenous ways of knowing a more robust part of both political ecological praxis and pipeline impact assessments. To do this in a respectful way demands an openness to a multiplicity of truths, ontologies, and spatio-temporalities, as well as recognizing the impossibility of reconciling Indigenous geographies and political ecology into a single, explanatory edifice. Indigenous temporalities not only supplement political ecology but also serve as inherently valuable sources of guidance for Indigenous governance systems, with far reaching consequences for the redistribution of land and decision-making power to Indigenous and nonhuman communities. Indigenous geographies and political ecology should aim to unburden Indigenous peoples from colonial institutions that ultimately work to erase spatiotemporal differences. Even if Indigenous temporalities have a strategic political function in impact assessments conducted by colonial states, they cannot be easily assimilated into colonial logics because they are incompatible with the internal spatiotemporal order of the state. In the analysis that follows, I make explicit the temporal aspects that were expressed in Anishinaabe engagement with the review process for the Line 9 pipeline reversal.

\section{Background}

In 1976, Enbridge Inc. (then called Interprovincial Pipe Line Ltd.) built the Line 9 pipeline, which runs from Aamjiwnaang (Sarnia, Ontario) to Tiohtià:ke (Montréal, Québec) and is comprised of two segments, Line 9A (from Aamjiwnaang to North Westover, Ontario) and Line 9B (from North Westover to Tiohtià:ke). Line 9 has operated for more than 40 years without the consultation or consent of any of the 18 Indigenous nations along its route, including Anishinaabeg, Haudenosaunee, Lenape, and Métis communities. Indigenous laws, referring to sets of legal practices distinct from colonial law - including processes of Anishinaabe Chi Inaakonigewin (Natural law) - were violated through the imposition of Line 9. Numerous treaty agreements between Indigenous and settler nations were also violated - the Two-Row Wampum, the Treaty of Niagara (1763), the Royal Proclamation (1764), the Haldimand Proclamation (1784), the Longwoods Treaty (1822), and Treaty 29, among others. Line 9 originally carried conventional crude oil eastward as part of Enbridge's 3,000 km Lakehead system (Brooks 2014). With NEB approval, Enbridge reversed the flow in 1997 and began operating Line 9 from east to west. In 2012, less than two years after the now infamous Kalamazoo River spill (from Line $6 \mathrm{~b}$ on the same Lakehead system), Enbridge applied to again reverse the direction of Line 9, increase its capacity, and transport heavy crude oil and diluted bitumen from the Athabasca tar sands.

The NEB approved the reversal of Line 9A, the section between Aamjiwnaang and Westover, Ontario, in July 2012. Enbridge then applied to reverse Line 9B, the stretch from Westover to Tiohtià:ke, in November of the same year. After a series of hearings, the NEB provided conditional approval for the 9B application in March 2014. Despite Indigenous-led direct action and blockades, as well as concerns raised by both Indigenous and non-Indigenous intervenors about risks to the environment, human health, and Indigenous rights, the NEB granted Enbridge final approval in September 2015 (Hunsberger and Awasis 2019; Grant 2014; Scott 2013). During this time, Anishinaabe people met in Elder's, Women's, Men's, Two-Spirit, and Youth Councils at Water Gatherings and at Niwiijiiwok Dodemag (Clan Gatherings) to strategize for resurgence and water protection, as well as to discuss actions to take in opposition to Line 9 (Jewell 2018). In November 2016, Deshkan Ziibiing Anishinaabeg (Antler River, or Chippewas of the Thames First Nation) challenged the NEB's decision in the Supreme Court, citing the Crown's failure to consult the nation, which they argued was in violation of their Aboriginal rights enshrined in section 35 of the Constitution Act (1982). Canadian constitutional law is founded on treaty agreements with distinct Indigenous legal systems that provide the Crown with a duty to consult Indigenous nations when a decision could impact their rights (Borrows and Coyle 2017). Lawyers representing Deshkan Ziibiing argued that the NEB's mandate was too narrow to consider the full range of impacts and consultation was inadequate due to the project-specific scope. Broader issues pertaining to climate change, the tar sands, capitalism, and the cumulative impacts on Indigenous lands were also excluded from the review (Hunsberger and Awasis 2019).

In July 2017, the Supreme Court announced its decision that consultation with Deshkan Ziibiing had sufficiently satisfied the Crown's obligations (Chippewas of the Thames First Nation v. Enbridge 2017). The Supreme Court considered the consultation adequate because the Indian Act band council was given notice of the NEB hearing, participated in the process, and was aware that the NEB was the final decision maker. The 
Court supported the NEB's position that modifying an existing pipeline would only minimally infringe upon section 35 Aboriginal rights and that the conditions imposed on Enbridge would adequately mitigate risks. In response, Deshkan Ziibiing re-asserted their responsibility to the water and issued a request for Enbridge to cease operation of Line 9 within 30 days. Enbridge did not oblige.

The events described above fit into a larger story of mounting Anishinaabeg resistance to pipeline projects throughout Anishinaabe Aki, including opposition to the Line 3 replacement program, Line 4 expansion project, and the continued operation of Line 5 (Cragoe 2017; Hearne 2017; LaDuke 2015). Anishinaabeg from the Minnesota Chippewa Tribal Government that did not feel consulted through the colonial review process on Line 3 conducted their own public hearings and cumulative impact assessment (LaDuke 2015). As well, the 2017 Energy East pipeline application was withdrawn after Anishinaabe communities (Ginoogaming and Aroland First Nations) threatened to pursue a constitutional challenge after filing for an injunction in the Ontario Superior Court (Porter 2017; Sparks 2017). The review process had already been delayed in September 2016 when the hearings were suspended to allow for the NEB to assign new board members to the Energy East panel following two of the panelists' meeting with a consultant working for TransCanada (now TC Energy) to discuss the proposal (Cheadle 2016). Acknowledging limitations in its energy reviews, the Canadian government established two Expert Panels that produced nonbinding recommendations on how to restore public trust in the institution (Expert Panel on the Modernization of the NEB 2017). Some of these suggestions are reflected in Bill C-69, passed by the Senate June 2019, containing changes to impact assessment and to the Canadian energy regulator. As this legislation slowly comes into force, it is useful to consider how Indigenous temporalities can provide a more expansive understanding of what constitutes a comprehensive impact assessment and meaningful engagement with Indigenous rights.

\section{Izhichigewin (purposeful ways of doing)}

To explore how Anishinaabe temporalities diverge from settler time in the 2012-2017 Line 9 pipeline dispute in the Great Lakes region, this article uses analysis of documents from Canada's National Energy Board and in-depth interviews with Anishinaabe pipeline opponents $(n=26)$. At the time, NEB was the Canadian regulatory body responsible for interprovincial and international oil and gas pipelines. In this section, I will provide a more detailed explanation of my data collection and sampling strategy, expand upon my biskaabiiyang (decolonizing) research approach, and describe my approach to analysis. Both data and analysis come from mutual exchange and ongoing relationships with participants. Document collection focused on written evidence submitted by Anishinaabe intervenors in advance of the 2013 public hearings. The NEB's temporal modes were analyzed using the Reasons for Decision report on the Line 9B Reversal and Line 9 Capacity Expansion Project, the Supreme Court's decision document, and National Energy Board Act. These documents were initially coded line-by-line using themes from energy justice literature as part of a larger project, before coding was refined based on ideas from temporal justice. A full list of coded documents and a more detailed description of the methods used for document analysis can be found in Hunsberger and Awasis (2019).

Interview participants were identified using positional criteria based on their clan and active involvement in Anishinaabe pipeline opposition. Snowball sampling enabled recruitment through participants' community networks. Since the first participants could influence those recommended as future participants, sampling began with a two-spirit, woman, and man from each of the seven original Anishinaabe Dodemag (Clans) when possible - Ajijaak (Crane), Maang (Loon), Migizi (Eagle), Waabizheshi (Marten), Waawaashkeshi (Deer), Makwa (Bear), and Mikinaak (Turtle). This approach draws on the strength of dodemiwan (clan governance) to build consensus and help minimize community bias that could result from snowball sampling being limited to the families and genders of the first participants.

In Anishinaabemowin, the word biskaabiiyang describes a cyclical process of decolonization as "returning to ourselves" (Geniusz 2009). This approach seeks to decolonize Anishinaabeg peoples, lands, and ways of knowing by describing concepts within Anishinaabe culture and language. I use Anishinaabe methods of inquiry, namely my experiences living as niizh manidoo (two-spirit), visiting with community 
members, and living in community. Biskaabiiyang is concerned with returning our bodies to the lands, the web of relationships and ethical practices that generate Anishinaabewin (lived expressions of being Anishinaabe). Decolonial theory and praxis is deeply informed by what the land, as a system of reciprocal relationships and responsibilities, can teach us about living in the world in non-hierarchical and nondominating ways. Coulthard (2014) calls this grounded normativity, the place-based foundation of Indigenous practices and knowledge that structures our relationships with humans, nonhumans, and the world around us. These ethical frameworks are the bases of Indigenous nationhood and social, political, and economic systems. Simpson (2017) maintains that Anishinaabewin, what makes us Anishinaabe, is the closest thing to Coulthard's grounded normativity within Anishinaabe gkendaasowin (knowledge). In this sense, Anishinaabe is something we are and something we do at the same time (Doerfler et al. 2013). Anishinaabewin is an action, it is embodied gkendaasowin that is lived, experienced, and attained through direct interaction with the land (Pine 2016). I do this by using niizh manidoo (two-spirit) as method to establish and maintain relational accountability.

Niizh manidoo is a spectrum of culturally rooted gender expressions that are embedded in Anishinaabewin. Using niizh manidoo as a method to analyze settler colonialism as a structure of temporal processes puts forward an expansive, nonhierarchical conceptualization of dispossession to include Anishinaabe lands and bodies (Simpson 2017). Niizh manidoo bodies hold theory and critical analysis that straight bodies do not, because we have experiences with heteropatriarchy as expansive dispossession. Niizh manidoo as method not only generates theory and praxis, it helps restore niizh manidoo bodies as political orders within Anishinaabe nationhood (ibid). Niizh manidoog (two-spirits) hold part of the theory Indigenous nations need to resist settler colonialism. It is important that Indigenous people are doing Indigenous research because we have life-long learning and experience (Wilson 2008). I have a natural advantage in the sense that niizh manidoo endaaw (I am two-spirit) and have sustained long term connections with Anishinaabe Aki (land), communities, and pipeline resistance movements. Recall that gkendaasowin is personal and relational; knowledge is shared with me because of who I am and my relationship to the community, and it is not possible to compartmentalize relationships built through this research apart from the relationships that make me who I am (Absolon 2011; Wilson 2008).

Visiting with humans and nonhumans, in accordance with cultural protocols, nurtures relationship building. This entailed taking my body out onto the land and directly engaging with Anishinaabe people who are building pipeline resistance movements. Unless otherwise noted, quotes were spoken directly to me. The semi-structured interviews were open-ended and dialogue-based, allowing for the mutual sharing of information through focused discussion (Wilson 2008). Visiting is an enjoyable form of knowledge sharing that can be considered a core Anishinaabe political practice (Simpson 2017). Resistance leaders such as Tecumseh and Pontiac personally traveled and visited communities both within and outside their own nations for several years before mobilizations took place. Simpson (2017: 224) calls this the "hard work of being present"; building lodges, harvesting medicines, preparing food, taking care of elders and children, singing, grieving, and dreaming, are all practices that comprise the basis of Anishinaabe gkendaasowin.

The research builds upon relationships between participants' ideas in a way that reflects shared understandings of Anishinaabe time. As opposed to triangulation, in which accuracy is generated by three separate views aligning, relational knowledge "encircles" a concept (Wilson 2008). From where each person is positioned in the circle, their spatiotemporal relation is different. Each participants' unique relationship to time is valuable because of this difference. Anishinaabe time is not any single set of ideas - it is the interaction between many diverse temporalities and collective meanings, including discord, that make sense within Anishinaabewin.

\section{Gegoo ngiimkaan (something I found)}

This section describes gegoo ngiimkaan in divergent Anishinaabe and settler temporal understandings enacted during the Line 9 decision-making process, drawing on the NEB's Reasons for Decision, the NEB act, the Supreme Court decision, intervenor evidence, and interviews with Anishinaabe pipeline opponents. First, I will expand on how Anishinaabe scholars engage with the temporal concepts of kinship, queerness, 
continuity, and prophecy. These perspectives are not intended to be representative of all Anishinaabe temporal modes or concerns, and do not amount to an essential definition of time for all Anishinaabe people. Rather than trying to name all possible aspects of Anishinaabe multi-temporalities that are irreducible to settler time, my aim is to emphasize aspects of Anishinaabe space-time that may be helpful for others carrying out work in temporal justice and Indigenous self-determination. Anishinaabe gkendaasowin is based on a multiplicity of truths and instigates wide intellectual engagement, while centering place-based ways of living that cannot be separated from the language and land (Dumont 2015; Pine 2016; Simpson 2017). Place is a "peopled cosmos of influencing powers" (Simpson 2017: 22). Within Anishinaabe ontologies and epistemologies, all plants, animals, trees, rocks, rivers, and lakes are sentient beings who have their own identity, language, knowledge, law, rights, and temporal relations (Kimmerer 2003). Anishinaabe time is relational, intergenerational, and connected to the Seven Fires Creation Story and Seven Fires Prophecy. Autonomy is valued for resiliency, queerness is normalized, and time cannot be easily dissected into the past, present, and future.

Creation stories set the ontological framework within which the ceremonies, songs, and stories of Chi Inaakonigewin can be interpreted in personal and culturally inherent ways (Simpson 2011). Niigaanii Oshkaabewis (Raymond Deleary), Maang Dodem (Loon Clan), Executive Director of Operations at Atlohsa Native Family Healing Services, and former Band Councilor and Senior Policy Analyst of Chippewas of the Thames First Nation stresses, "Our Creation story always has to be at the foundation of how we make decisions for the future." Wawasay Guhmee Kwe (Dawn-Estelle Miskokomon), Mishiikenh Dodem (Turtle Clan) from Bkejwanong (Walpole Island First Nation) and Deshkan Ziibiing (Chippewas of the Thames First Nation) adds that "as Anishinaabe People, our laws are founded in our relationship to creation." There are several different creation stories among the Anishinaabeg confederacy that can each take several days to tell. Through Anishinaabe creation stories we come to understand that we are not only the land, we are also both creator and creation. We are told different peoples were given different creation stories and all of them are true (Dumont 2015). Reclaiming the context of Chi Inaakonigewin means inserting ourselves into these stories (Dumont 2015; Simpson 2011). Rather than referring to the abstract "first person" who descended from the sky world, I say the first niizh mandioo (two-spirit) was lowered to earth - the story is personal (if you are a woman you say the first woman, and if you are a man you say the first man). During the first niizh manidoo's slow descent, they stop to look back from where they came and to look forward to where they are going. Their astonishment grows as they get closer to their mother, the earth, and can see more and more of the life growing from her. Suspended in space, the first niizh manidoo wonders how they will be able to fit into this family and learn to live in balance like their elder relatives, the other beings below (Dumont 2015). Niiobinesiik (Summer Bressette), a Maang Dodem (Loon Clan) community organizer, emphasizes:

We need to go back to those original protocols of living on the land and remembering our teachings that we were the youngest beings put on this Earth. There was a sacred agreement, treaties that were made between the animals, Creator, and Anishinaabe to live on the land, so we are humble. We are humble before all of creation.

As the last beings to be created, humans are the only beings on earth that need to learn Natural law by observing their nonhuman relatives, Natural law is instinctual for all other beings (Benton-Banai 1988; Dumont 2015). The plants, animals, and other nonhumans can survive without us, but we cannot survive without them (Giniwgiizhig 2013). The first niizh manidoo stops again during their descent, concerned that if they can see this much life, there must be even more unseen life that they could harm when they come down upon the earth; this is not how they want to meet their family for the first time. After pausing once more in wonderment, they decide to point their toes and come down gently amidst the life, carefully landing between blades of grass so as not to disturb them (ibid). Oshki Migizi Kwe (Danielle Boissoneau), Gete Mishiikenh Dodem (Old Turtle Clan) told me: "The human impact on the earth has to be less, as invisible as possible. Our footprint has to be zero and that goes back to our teachings where we talk about walking on the earth as lightly as we can."

Anishinaabe creation stories and Chi Inaakonigewin direct us toward dodemiwan (the clan system). Dodemiwan is relational and relies on animals' support for Anishinaabeg (Jewell 2018). The animals adopted 
us and are our true family (Dumont 2015). Waabizheshiwag (pine martens) are very literally my kin. We learn how to live mino bimaadiziwin (a good way of life) from our family: Shkaakaamikwe (Earth Woman), Nohkomis Giizis (Grandmother Moon), Mishomis Giizis (Grandfather Sun), and all our relations. Mino bimaadiziwin can be understood as the mutual flourishing of interconnected natural and cultural communities (Doerfler et al. 2013; Simpson 2011). Waawiyebii'jigan Kwe (Eva Jewell), Ma'iingan Dodem (Wolf Clan), Assistant Professor in the Sociology Department at Ryerson University, and former Community Development Coordinator and Research Analyst at Chippewas of the Thames First Nation observes,

We are all already in our large extended families anyway. Let's try to remain close to that structure because remember, our large extended families and our kinship are how we maintain our rights, it's how we maintain our ties to the land, it's how we maintain and carry on our continued jurisdiction and our presence in this place.

Dodemag (Clans) are repositories of intergenerational knowledge and responsibilities based on an extended family network embedded in the land (Giniwgiizhig 2013). Yet responsibilities are not bestowed upon individuals by the collective; instead, individuals choose to take on responsibilities based on their unique gifts and abilities (Simpson 2017).

Individual autonomy is valued for resiliency and long-term sustainability; if our practices are diverse, we have a variety of knowledge and solutions available before problems even arise. Indigenous queer normativity refers to when difference is not treated as difference but as normal (Simpson 2017). In this sense, Anishinaabe gkendaasowin can be considered queer because it honors epistemic diversity and multitemporalities. Even within the same nation, community, family, and individual, different ceremony societies will entail interrelated yet distinct temporal modes. Queerness celebrates variance, including straightness, and provides for Indigenous self-determination (ibid). The normalization of epistemic difference is related to emplaced self-determination that rests upon understandings of Indigenous identity and social organization as constituted by the landscape (Powell 2015). Simpson (2017) discusses two-spirit and queer Indigenous people in relation to daylight: "At every point in the day, there is a different amount of light - it is not just day and night. Our circles are not just men and women. There is an endless amount of diversity in our communities" (140). Queerness embedded in Anishinaabe spatio-temporalities highlights the value of niizh manidoog as knowledge holders and political orders in a land-based kinship system. As Oshki Migizi Kwe notes,

These resistance movements are driving us back towards community clan-based and nationbased decision making... Some gatherings I've been to are starting to return to clan-based gathering and having people sit in their clans. It's another way to start looking past gender as the main thing that gets people sitting where they are sitting in ceremony. It's more complex than that. The women need to reclaim their roles, two-spirits also need to reclaim their roles, because we've been so completely downtrodden by patriarchy and colonization.... we need to be sitting in our clans so that we can make clan-based decisions and start returning to our governance systems which are based in clans and clan mothers.

Anishinaabe time is not dissected into past, present, and future; not only does the past influence the present and future, but our desired futures shape how we engage with the past and present. Regarding continuity, Simpson (2017) describes the Anishinaabeg understanding of time coded in the etymology of the word biidaaban (dawn). The prefix "bii" refers to the future coming toward you, "daa" is the verb for presently living in a specific place, and "ban" is the verb used when something no longer exists. In this sense, Anishinaabe time can be understood as the past and future colliding in the present. "Everyday embodiment is therefore a mechanism for ancient beginnings" (Simpson 2017: 193). Dodemiwan, grounded in land-based power, exists across space-time in a decentralized system generated and maintained by Indigenous people themselves. 
In Anishinaabemowin, aanikoobijigan refers to both ancestor and descendant (Whyte 2018). This suggests that Anishinaabe time is intergenerational and that we are simultaneously living alongside past and future relatives. The extended network of relations can be visualized as spiraling through time in seven directions - inward, upward, downward, and outward in the four directions (Simpson 2011). Spiraling time unfolds through our own transformation from descendant to ancestor and our interaction with the actual and/or potential actions of our ancestors and descendants (Whyte 2018). As conceptual tools, biidaaban and aanikoobijigan provide further context for Anishinaabe decision-making and self-determination. It is critical to understanding Anishinaabe time and stories of Chi Inaakonigewin (Natural law) not to limit the relevance of old stories by interpreting them as exclusively occurring in ancient times (Richotte 2013; Simpson 2017). Dodemiwan relies upon maintained relationships with the past ancestors and future descendants of presentday human and nonhuman relatives.

The Seven Fires Prophecy is one of the most epic stories in Anishinaabe gkendaasowin (ways of knowing) given to us by our aanikoobijiganag (descendants/ancestors) that relates to colonialism and decolonization, and it invokes the non-linear, cyclical nature of resurgence (Jewell 2018; Simpson 2011). As many interview participants, including Oshki Migizi Kwe, described, "we are living in a time of prophecy." For Anishinaabeg, the work of revitalizing dodemiwan governance and resisting colonial violence is embedded in the Seven Fires Prophecy (Jewell 2018). Long ago, in a time of flourishment and abundance, the Anishinaabeg lived on the east coast for many generations (Giniwgiizhig 2013). Seven prophets came to the Anishinaabeg from the north and made a prediction for the future (Dumont 2015). Each of these seven prophecies is called a Fire and refers to a particular era of time in the future (Benton-Banai 1988; Dumont 2015). The first three prophecies set in motion the great migration from the east coast of Mikinaak Minis (Turtle Island or North America) to the western shores of Gichi Gamiin (the Great Lakes), where the food (wild rice) grows on water (Benton-Banai 1988; Dumont 2015; Simpson 2011). The Fourth, Fifth, and Sixth Fires foretold of the coming of light-skinned people, the church and missionaries, and the residential school system, respectively. Many Anishinaabe people were stripped of our identity, language, and culture during this time, but we were also preparing for the Seventh Fire; sacred items were hidden, ceremonies were intentionally conducted underground with children present, and families retreated further into the bush and moved to city centers when possible to avoid Indian Agents. The seventh prophet foretold of a time the Anishinaabeg would retrace our ancestors' path, remember who we are, relearn our names and clans, and return to Anishinaabe bimaadiziwin (ways of living).

Many Anishinaabeg scholars believe we are currently at the beginning of the time of the Seventh Fire; this generation is Oshkimaadiziig (the New People of the Seventh Fire) (Dumont 2015; Simpson 2011). Oshkimaadiziig have responsibilities to past and future generations to revitalize Chi Inaakonigewin and dodemiwan. "Our responsibilities for resurgence pre-existed before we were present on the earth" (Simpson 2011: 66). The seventh prophet also told us that the Oshkimaadziig would be forced to decide between two roads, the road of destruction or the road of spirituality (Dumont 2015). Niigaanii Oshkaabewis explains:

The Anishinaabe Worldview is based on prophecies that we heard way back when and one of them is that we knew we'd be in this place right now, where there is a utilization of resources, modernization and technology, and everyone lives in these two worlds, and we are struggling to figure out how we are going to continue to do that. The caution from our prophecy is that if we continue to go down this path where we are just continuously, as a society, striving for the false promise of money and resources, then we need to be really careful about that because it's going to lead to a path of destruction, environmental destruction, societal destruction, things that we won't be able to turn back and fix.

The road of destruction relies on technological solutions and is void of spirit; it is well-trodden and if taken will lead to the destruction of all peoples. The road of spirituality involves all peoples returning to their original ways of living and embodying mino bimaadiziwin (a good way of life). If the spiritual path is taken before the waters are unable to heal themselves, it is possible we can light the eighth and final fire of peace 
(Benton-Banai 1988; Dumont 2015). Neegonee (Dennis Whiteye), Makwa Dodem (Bear Clan) and Manager of Community Services at Atlohsa Native Family Healing Services, shared that "the Eighth Fire, that next generation that's coming, they are going to be more equipped with knowledge and responsibilities, so all I can do is do my best to be that teacher that makes them better than I am." There is a sense of urgency in this story; Oshkimaadziig are the generation on which the future depends, and we have a responsibility to speak for all our relations. Oshki Migizi Kwe elaborates upon this: "Oshkimaadziig, this new people that are coming, are rising up because they remember what it means to have freedom, and not freedom in the sense of democratic, first to the post, colonial kind of freedom, but a freedom of spirit and a freedom of mind." According to the Seven Fires Prophecy, there is much decolonization work still to be done to improve Indigenous-settler relations on Turtle Island and light the Eighth Fire (Simpson 2011).

Anishinaabe temporalities provide an ongoing break from linear thinking. While doing the work of the Seventh Fire, it is important to be mindful that manidoog (spirits) that animate prophecy have their own distinct temporal relations. As well, Anishinaabe people have been given specific "new" ceremonies throughout time, demonstrating the relative regularity of what non-Indigenous scholars would refer to as "prophets" (Miller 2013). Temporal justice provides a means of pluralizing temporalities to help facilitate expressions of self-determination that do not depend on institutionality (Rifkin 2017). Anishinaabe time can function as a tool for the resurgence of dodemiwan in decision-making about energy schemes, and the seven generations principle in impact assessment. Temporal justice involves providing time for Anishinaabe people to restore dodemiwan, rebuild relations with nonhumans, and attain consensus, as well as considering the cumulative impacts on Anishinaabe Aki, seven generations before and after the proposed project would be undertaken.

\section{Periodicities}

Periods of time tend to reoccur in distinct intervals that serve as the basis for energy governance. Periodicities that were enacted by settler institutions involved in the Line 9 dispute included election cycles, court sessions, and the financial year. The NEB regulates interprovincial and international oil and gas pipelines in accordance with the NEB Act. The NEB Act describes the NEB's quasi-judicial power, with the rights and privileges of a superior court, to make decisions that are legally binding and enforceable (NEB Act 2016). Outlining financial requirements for pipeline applications, the NEB Act requires consideration of a company's financial statements. Based on a review of Enbridge's statements from previous financial years, in the Reasons for Decision document, NEB Panelist Richmond raises a concern that in the event of an accident, the applicant (Enbridge Pipelines Inc.) could choose not to access the full spectrum of financial resources held by its parent company (Enbridge Inc.). Myeengun Henry, former Chief of Chippewas of the Thames First Nation and Manager of Conestoga College's Aboriginal Services elucidates:

I know who put those Supreme Court justices in place, I know who put the National Energy Board in place, and I know who's working for the legal firm that is against us. When people hear that part, they don't realize that Stephen Harper had placed all these people and he is propipeline. That's the part that we need people to know, he stacked it so bad that nobody could have won that battle... that process can't work ... they can investigate whether treaty rights are infringed on, but they can't make that determination in the same board. You can't be judge and jury at the same time and that's exactly what happened in this case, the same board who approved these pipelines investigated whether they infringed on treaty rights and then made that determination as their own judge.

All Supreme Court judges are appointed by the Prime Minister, an elected representative and settler election cycles impact Indigenous rights and lands, even after individuals are no longer in particular elected positions. Between 2011 and 2014, then Prime Minister Stephen Harper, known for claiming Canada has "no history of colonialism" (Coulthard 2014), appointed six of nine Supreme Court Justices that heard the Line 9 appeal (Supreme Court Decision 2017). Although the Line 9 Supreme Court decision was unanimous, both 
Supreme Court justices who authored the decision were appointed by Harper, who now works for Enbridge's law firm, Dentons.

Settler institutional time has been used to displace Anishinaabe dodemiwan governance and underlying temporal modes. The elected governance system has been imposed on Anishinaabeg nations and many other Indigenous communities on Mikinaak Minis (Turtle Island). Under Indian legislation, elected councils have very limited jurisdictional powers to implement laws and regulations (Morden 2016). A split leadership weakens the negotiating power of Indigenous nations, with original forms of governance and state-sanctioned elected councils negotiating with one another as well as with colonial institutions (Kulchyski 2013). The Line 9 NEB hearings and Supreme Court only recognized representatives from elected band councils in the formal proceedings.

Both settler and Anishinaabe temporalities recognize recurring changes in sunlight, lunar phases, seasons, and the climate. Anishinaabe time is distinct in the periodicities it employs because governance practices and ceremonial life are organized around moon cycles and seasonality. Binesi Aanakwad (Vanessa Gray), Makwa Dodem (Bear Clan) Community Organizer describes how:

We always come together in our moon ceremonies and we always talk about the concerns we have for the community and the environment. Ceremonies bring out our spirit in a way that we can talk about these issues in a meaningful way. In any other setting it wouldn't feel like we would be strong enough to have these intense conversations about the environment and our health.

The 13 Moon calendar marks seasonal change and the periods of time when different activities are undertaken. For example, O'demin Giizis (Strawberry Moon) and Manoominike Giizis (Ricing Moon) reflect the very real changes taking place on the land at that time, related to the change of the seasons (Horton 2014). Seasonality does not refer to settlers' rigid delineation of four seasons, but rather how annual environmental changes gradually transition with our modes of harvesting, observing, storing, and consuming sometimes hundreds of plants, animals, and insects (Hatfield et al. 2018). Periods of seasonal change differ in length from year to year and remind humans of their responsibilities (Middleton 2015). Temporal concepts in the Anishinaabemowin language indicate that there are six seasons based on biogeophysical observation: ziigwan (when the ice breaks up), miinokamin (when the berries start to grow), dagwaagin (when the leaves change color and fall), oshkibiboon (when the new snow falls), and biboon (when the snow is frozen and crusted) (Davidson-Hunt and Berkes 2003). Interview participants emphasize the embodiment of seasonal knowledge and experience, noting the distinct smells of rain, open water, and fallen leaves, among others. Participants also raise concerns about climate change impacting the flow of the seasonal cycle that governance practices are based upon, yet they highlight that Anishinaabe ways of knowing can adapt to changing climate conditions.

In affidavits submitted to the NEB, then band council Chiefs from Aamjiwnaang and Deshkan Ziibiing (Chris Plain and Joe Miskokomon, respectively) refer to a seasonal pattern of land use as an "annual round." They confirm that community members continue to practice the same kinds of seasonal, land-based activities as their ancestors and descendants, and that there are hunting and harvesting sites directly adjacent to the Line 9 right-of-way (Miskokomon 2012; Plain 2013). A spill would severely disrupt these activities, and Miskokomon (2012) stresses that various colonial policies already imposed on Anishinaabe people also impede community members' ability to carry out this annual cycle.

\section{Timeframes}

Timeframes refer to specific periods of time in which an activity is expected to take place in decisionmaking. The NEB uses a relatively foreshortened timescale in decision-making, not invoking decades or centuries prior as a basis for action. In the 2012 federal budget, the Harper regime introduced dramatic changes to the environmental assessment process in Canada, shortening the timeframes of public reviews for big energy projects (Scott 2013). For Line 9, short notice was given for public meetings, and initial meetings 
were held after the registration deadline to participate in the NEB process had passed (Hunsberger and Awasis 2019). This reinforces the temporal hegemony of rapid capitalist development for profit, based in a belief that there is limited time for environmental assessment because economic growth will come from an accelerated regulatory system (Huebener 2015). The narrow mandate of the NEB and its project-specific scope provided a rationale for evading concerns about equity within and between generations (Hunsberger and Awasis 2019). The NEB also undermined the role of children in decision-making by abiding by an implicit limit on the number of years a person must live before they can participate in formal decision-making; NEB panelists for the Line 9 hearings were exclusively adults.

Anishinaabe time supports more expansive and open-ended timeframes than the NEB. Dennis Plain, Adik Dodem (Caribou Clan) describes how in dodemiwan "we sat and talked about the pros and cons, for weeks, months, until we all came to a conclusion." In these deliberations, lasting as long as they need to, many Anishinaabe people feel a responsibility to seven generations before and after themselves. Waawiyebii'jigan Kwe details how "We use our knowledge from seven generations back, stand here in the present and think how all of our actions will impact the future." The Seven Generations principle comprises the basis of understanding that a person's material and spiritual responsibilities extend beyond the individual, into the past and future (Horn-Miller 2013). Nearly all interview participants refer to the Seven Generations concept.

Anishinaabe time can also involve a disinclination towards counting years in a linear, numerical chronology (Huebener 2015). Age is often described in relation to the general life stage of the person (childhood, adolescence, adulthood, elderhood etc.) (Anderson 2011). Participants emphasize the important role that both children and elders have in decision-making and policy development. Wawasay Guhmee Kwe encourages decision-making that involves "all Anishinaabe, all stages of life, respectfully discussing these things in ways that honor a person's stage of life, and on the land, in creation, where the sanctioning of that discussion begins with the recognition and understanding of the peoples, humanity's relationship to creation, first."

\section{Kinship relations}

Kinship systems are generated throughout time in relation to material landscapes. The intergenerationality of family includes shared origins, inheritances, and trajectories. The idea that there is a single, proper form of kinship dynamics is a conception of personal development that is attached to a universal account of time (Rifkin 2017). In the NEB and Supreme Court decision-making processes, kinship relations were decoupled from the governance sphere, depoliticized and cast strictly as cultural. Settler familial relations, often based in the institution of the nuclear family, project an expected life course organized around heterosexuality and biological reproduction. The Indian Act system also employs this reproductive logic that reduces Indigenous kinship relations to blood quantum, monogamy, and binary, colonial gender expressions (Simpson 2017).

Anishinaabe understandings of kinship exceed the notion of the nuclear family. The Anishinaabe political structure is based on the interconnection of place-based kinship networks. These horizontal relationships extend through time and across Indigenous communities all over Mikinaak Minis (Turtle Island), far beyond the Anishinaabeg confederacy, Indian reserve lands, or biological family. The dodemiwan (clan governance) system of decision-making and territorial organization implements Chi Inaakonigewin (Natural law) through land-based kinship. This is reflected in the affidavit of Chris Plain, then Chief of Aamjiwnaang First Nation, who draws upon Borrows (2010) to describe how a person's dodem (clan) creates reciprocal obligations among fellow clan family members. Dodem leadership is decentralized and emergent, based on power generated with kinship relations from the land-up, rather than power appointed from the top-down (Giniwgiizhig 2013; Simpson 2017). Waawiyebii'jigan Kwe shares, "my work is really about shifting the mentality from the top-down approach of governance, like believing in the Indian Act as a viable tool of governance, which it's not ... and shifting to resurging Anishinaabe ways of being, through our customary governance practices, through the clan system." This calls into question the legitimacy of the nation-state as the key locus of decision-making power, even as it dispossesses Indigenous political kinship systems. Interview participants express land-based kinship ties that have been disrupted by 
settler institutions. Family is a basic organizational unit in Anishinaabe society; undermining Anishinaabe temporalities by containing them within settler institutions poses a threat to family functioning by displacing non-linear temporalities (Kowal 2015).

\section{Nonhuman temporalities}

Nonhumans, including spiritual relations, have their own unique spatio-temporalities that provide the basis for mating, nesting, hunting, harvesting, migration, hibernation, and growth cycles, among others. The NEB discounts nonhuman entities in decision-making. The Aamjiwnaang and Deshkan Ziibiing band councils provided the NEB with maps outlining traditional land use areas that would be impacted by a spill, and the Environmental Assessment requested by the NEB identified many species at risk and their associated habitats within $120 \mathrm{~m}$ of work sites along the Line 9 corridor. When interpreted through colonial institutions, humans' relationships with nonhumans become reduced (limited in interaction) and unilateral (nonhumans are assumed unable to respond). Regarding her experience at the Supreme Court, Wawasay Guhmee Kwe similarly expresses that "it held no impact to our relationship to creation, it spoke nothing to our creation and relationship to Mother Earth. It said very little and it listened very little to the sounds of creation and what the messages were of creation." Participants also raised concerns that workers sent to conduct Environmental Assessments are often non-local and unfamiliar with when and where to find specific species on the land.

Fast-tracked assessments have resulted in workers spending inadequate time on the land, relationshipbuilding with locals and nonhumans, before conducting the study, resulting in underestimates of species at risk and potential impacts. Dennis Plain, Species at Risk Technician and Adik Dodem (Caribou Clan) recalls,

...we did a snake study and we found out that on all these pipeline environmental assessments it says there are no species at risk on Aamjiwnaang First Nation and there hasn't been for 20 years and we are like, what? ... I found 4 Butler's Garter snakes in an hour... They had a contractor from Toronto, fresh out of University, running the pipeline looking for snakes. She went to school but had never been in the bush, she's not going to find snakes on a First Nation.

Participants elucidate a connection to their clan's specific habitat (cranes' sensitivity to wetlands and pine martens' partiality to the woodlands, for example) and how life-long and ancestral experiences living in these landscapes strengthen one's ability to assess impacts. Nonhuman temporalities are not only acknowledged in Anishinaabe gkendaasowin (ways of knowing), they are centered in dodemiwan (clan governance). Biidaaban structures reciprocal relations between Anishinaabe people and dodem animals. Biidaaban presupposes the present and future existence of people as they appear in old stories. The people from long ago - human and nonhuman - still exist today (Nadasdy 2008). Anishinaabe temporalities are not only cyclical (same species, different individuals) but circular (same individuals in the present, past, and future). This distinction is important for understanding how Anishinaabe people engage with nonhuman agency; human and nonhuman nations exist in the present through our past and future intersocial relations. The past, present, and future societies of humans and nonhumans all exist in continuous interrelationship. Participants also emphasize that there is a power imbalance between human and nonhuman societies. In particular, Line 9 is seen as an infringement on water nations' responsibilities to all life.

\section{Discussion}

Three intersecting themes further connect divergent temporal modes in Line 9 decision-making to theories of temporal justice.

\section{Traditional/modern Indigeneity}

Although Anishinaabeg band councils provided the NEB with traditional land use studies, in colonial decision-making, "traditions" can only be regarded as "authentic" when they are supposed to emerge from an idealized past. In a linear progression of time, the distance between present-day Indigenous peoples and the 
source of authenticity is steadily increasing (Richotte 2013). Wawasay Guhmee Kwe describes how "we are in constant conflict with what is modern, what is state of the art, and what is authentic." The term "traditional" imposes settler understandings of history and time on Indigenous people, as when colonial courts maintain the power to deny Indigenous rights on grounds that they are not "traditional" (Ogden 2009). Settler time equates Indianness with pre-modern backward relations to "real" time, casting Indigenous nations as in need of colonial institutions to make decisions on their behalf (Huebener 2015; Rifkin 2017). In Anishinaabe gkendaasowin, the "traditional" defies all temporal limitations (Richotte 2013). Niigaanii Zhaawaashko Giizhigo Kwe (Giselle Dias), Waabizheshi Dodem (Pine Marten Clan), explains how "tradition evolves overtime, as we grow things have to change in certain ways, new language has to be created for new processes, new systems, that's how it needs to happen." Wawasay Guhmee Kwe describes this as an "old new way of thinking." The Seven Fires Creation Story and Seven Fires Prophecy are traditional stories because they emphasize reoccurrence, retain the ability to apply to Anishinaabe peoples in multiple temporal settings, and maintain a deep sense of continuity that connects the past, present, and future, in ways that do not center the moment of colonial contact. Temporal justice entails disrupting dichotomous traditional/modern understandings of Indigeneity to better provide for spatio-temporalities that are foundational to the resurgence of dodemiwan as a decision-making process.

\section{Historical presentism}

The primacy of the present in impact assessment involves "seeing the past through the lens of the present" (Foster 2017: 305). This includes the tendency to interpret historical grievances in terms of modern concepts that mirror the capitalist economy's focus on the short term, rendering us sensitive to the "slow violence" of environmental injury across extended time spans (Fitz-Henry 2017; Scott 2013). Settler temporal modes posit the present as an integrated whole against which historical events are juxtaposed, temporal orientations that do not fit dominant settler temporal modes are interpreted as abnormal fixations of the past, as opposed to being seen as alternative ways of being-in-time (Rifkin 2017).

In the NEB hearings on Line 9, Aamjiwnaang Anishinaabeg described how they have not received any revenue from oil transported across their territory in Line 9, despite its continued operation: constituting an ongoing infringement of their treaty rights. The Supreme Court decision acknowledges that the original Line 9 pipeline, installed in 1976, was approved and constructed without any consultation with Deshkan Ziibiing Anishinaabeg. Yet the Court also states that the "duty to consult is not the vehicle to address historical grievances" (Chippewas of the Thames First Nation v. Enbridge 2017). The original pipeline, despite being in contravention of Canadian law, is immune to the transgression when colonial violence is allocated to the past and divorced from questions of ongoing settler coloniality (Coulthard 2014). The Supreme Court decision refers to a modern concept of abstract treaty rights, without reference to any specific treaties or treaty violations. Situating colonial violence in the past makes it appear irrelevant to decision-making in the present.

Although abstract time, history, and the present are concepts that are critically important to settler time, they are less important and regarded with less esteem among Anishinaabeg (Richotte 2013). Kinship networks operating within the grounded normativity of Anishinaabewin provide us with an opportunity to govern ourselves by employing Anishinaabe spatio-temporalities as acts of temporal justice. Indigenous resistance movements are built within constellations of collectives, creating mechanisms for communication, accountability, consent/dissent, and shared decision-making with nonhumans in ways that amplify placebased relationships and practices (Simpson 2017).

\section{Temporal violence}

Indian policy has worked to reorient Indigenous knowledge and alter Anishinaabe experiences of time so that colonial geographies, political categories, and temporal concepts are naturalized. This process can be described as chrononormativity, a technique by which the practices of colonial institutions and regimes of asymmetrical temporal power come to seem like ordinary bodily modes (Rifkin 2017). The seeming inevitability of universal time as a reference functions as a background that normalizes colonial power relations in the present and projects them into the future (ibid). Settler time has been constructed socially as a 
form of power within the nation-state (Huebener 2015). Yet Anishinaabe temporalities do not indicate that institutionalized forms of Indigenous governance (such as elected Indian Act band councils) are inherently inauthentic modes of temporal assimilation (Rifkin 2017). Refusing "Indian" institutionalization does not necessarily mean rejecting formal Indigenous governance. The deconstruction of Indigenous temporalities could be used to discredit Indigenous institutional authority, especially in colonial contexts in which Indigenous nationhood continues to be subject to intense settler surveillance, state intervention, and regulation (Rifkin 2017; Simpson 2017).

Temporal justice is concerned with unequal valuations of time, the inequitable use of temporal power, the legitimation of power by means of control over time, and the institutionalization of a dominant time. Since debates about temporal justice remain largely unprepared to identify ways that structures of time reflect (de)colonial power relations, I offer the term 'temporal violence' to provide a framework for identifying, articulating, and responding to colonial violence in relation to temporal injustice. Temporal violence draws attention to the ways colonial systems impose an understanding of time as a self-evident normative framework that serves as the basis for Indigenous inclusion and recognition in decision-making. The theorization of temporal violence occurs in the absence of a shared temporal and natural world. The presumption of a shared time limits possibilities for enacting broader forms of Indigenous self-determination that reject settler efforts to manage the scope of decision-making using Indian policy.

Indigenous pipeline resistance movements are often comprised of a diversity of both inherent and acquired forms of temporalities and governance structures. Indigenous nations have incorporated settler temporal and institutional modes in response to colonial violence. However, the qualitative texture of Indigeneity comes from temporal formations that do not align with colonial state trajectories. In relation to Anishinaabeg resistance to Line 9, for instance, Myeengun Henry describes how "it's actually Natural law that we are fighting for." Echoing this sentiment, Niigaanii Zhaawaashko Giizhigo Kwe adds "all this land is Indigenous land and settlers need to be working off Indigenous law, period. It's not a matter of negotiating with people around how they negotiate with us. This is our land, these are our laws." Indigenous engagement within institutions is not the most effective strategy for revitalizing Indigenous temporalities and governance. There is also a risk of losing embodied knowledge if clan systems become institutionalized (Dumont 2015). Niigaanii Oshkaabewis illuminates how:

Our concepts of inherent and Natural law do not fit within, nor are they visible within the Canadian constitutional framework. That's difficult, we are still dealing with a situation where our concepts, our perspective on the environment, on Natural law, just clash with the Canadian framework of environmental law because their framework is based on capitalism and resource exploitation, and the best and highest use of land, based on a currency system and gross domestic product, and ours isn't. Our value is based on the environment providing everything we need to sustain ourselves and it'll be that way forever, as long as we only take what is needed, and we try to live by that principle. So, they just clash inherently from the beginning and still, to this day, the Indigenous perspective, the Chippewas of the Thames perspective on what is inherent rights and what is Natural law, and our understanding of the relationship to the land, is completely foreign to everything that is happening in the Supreme Court.

Indigenous temporal sovereignty points us toward "other than 'institutionally recognized'" temporal structures (Rifkin 2017). Indigenous assertions of land rights are often connected to deeper pursuits of national liberation and resistance to capitalism and colonialism (Coombes et al. 2012; Burow et al. 2018).

\section{Conclusions}

While walking among the poplar, walnut, and maple trees along Deshkan Ziibiing (Antler River), I visit with the same waters our ancestors interacted with, and the same waters that will be experienced by future generations. In this sense, the river transcends space-time, and connects generations in both healing and destructive ways, depending on our ongoing relationship with them (McGregor 2013). I am simultaneously 
enmeshed in relations to my human and nonhuman ancestors who travelled these waterways, the colonial temporality that sanctions environmental violence, and the river herself as a person with decision-making power. I conclude with this image of Deshkan Ziibiing to highlight that Indigenous governance operates within a web of nonhuman, Indigenous, and settler temporalities. Although we exist in a continuum of Indigenous temporalities and settler time, Indigenous ways of living that focus on reciprocal, place-based relationships and responsibilities unravel the singularity of the land and the universality of time.

Anishinaabe spatio-temporalities orient individuals' and collectives' assessment and rejection of Line 9. In this article I have introduced and reshaped several key theoretical concepts that I hope will be of use to others who wish to exercise and promote critical Indigenous temporalities. 'Temporal violence', which I advance as a means of identifying and responding to inequitable valuations of temporalities in relation to colonial power, offers one possible framework for working toward a deeper understanding of temporal justice in reviews of energy projects. In both Indigenous geographies and political ecology, there has been little attention given to temporal violence. Examining temporal violence through embodied resurgence of Indigenous spatio-temporalities, rather than the continued reliance on linear temporal progression, provides for communities' capabilities to decolonize energy governance. Future research should look for ways to shift toward centering Indigenous temporal modes in decision-making. This implies that researchers should also strive to understand how decision-making practices are embedded in kinship with the land. Indigenous multitemporalities have the potential to reshape ecosocial relations and dominant understandings of time. They aspire to be transformational and offer ways of socializing ourselves into more equitable forms of time, opening new spaces for temporal multiplicity to guide governance, while challenging entrenched hierarchies of colonial power.

\section{References}

Absolon, K.E. 2011. Kaandossiwin: how we come to know. Halifax: Fernwood Publishing.

AFN. Written evidence of Aamjiwnaang First Nation; NEB File OF-Fac-Oil-E101-2012-10 02, Document C1-5-1, AFN: 2013.

Anderson, K. 2011. Life stages and Native women: memory, teachings, and story medicine. Winnipeg: University of Manitoba Press.

Bebbington, A.J. 2004. Movements and modernizations, markets and municipalities: Indigenous federations in rural Ecuador. In Peet, R. and M.J. Watts (eds.). Liberation ecologies: environment, development, social movements. London: Routledge. Pp. 394-421.

Benton-Banai, E. 1988. The Mishomis book: the voice of the Ojibway. Saint Paul: Red School House.

Benton-Banai, E. 2008. Anishinaabe almanac. M'Chigeeng, ON: Kenjigewin Teg Educational Institute.

Borrows, J. 2002. Recovering Canada: the resurgence of Indigenous law. Toronto: University of Toronto Press.

Borrows, J. 2012. (Ab)originalism and Canada's constitution. Supreme Court Law Review 58: 351-398.

Borrows, J. and M. Coyle. 2017. The right relationship: reimagining the implementation of historical treaties. Toronto: University of Toronto Press.

Bowles, P. and H. Veltmeyer. 2014. The answer is still no: voices of pipeline resistance. Halifax: Fernwood Publishing.

Brooks, M. 2014. The cautionary tale of Kalamazoo: the still-unfolding horrors of spilled bitumen in Michigan's Kalamazoo River explain why more pipelines are an unacceptable risk. Alternatives Journal 40(1): 22-30.

Burow, P.B., S. Brock and M.R. Dove. 2018. Unsettling the land: indigeneity, ontology, and hybridity in settler colonialism. Environment and Society: Advances in Research 9(1): 57-74.

Carroll, C. 2014. Native enclosures: Tribal National Parks and the progressive politics of environmental stewardship in Indian Country. Geoforum 53: 31-40.

Castree, N. 2004. Differential geographies: place, Indigenous rights and 'local' resources. Political Geography 23(2): 133-167. 
Castree, N. 2009. The spatio-temporality of capitalism. Time and Society 18: 26-61.

Cheadle, B. 2016. National Energy Board cites 'apprehension of bias,' drops Energy East reviewers. CTV News 9 September.

Cicciarello-Maher, G. 2017. Decolonizing dialectics. Durham: Duke University Press.

COTTFN. Written evidence of Chippewas of the Thames First Nation; NEB File OF-Fac-Oil-E101-2012-10 02, Document C2-6-3; COTTFN: 2013.

Coombes, B., J.T. Johnson and R. Howitt. 2012. Indigenous geographies I: mere resource conflicts? The complexities in Indigenous land and environmental claims. Progress in Human Geography 36(6): 810-821.

Coombes, B., J.T. Johnson and R. Howitt. 2013. Indigenous geographies II: the aspirational spaces in postcolonial politics - reconciliation, belonging and social. Progress in Human Geography 37(5): 691-700.

Coombes, B., J.T. Johnson and R. Howitt. 2014. Indigenous geographies III: methodological innovation and the unsettling of participatory research. Progress in Human Geography 38(6): 845-854.

Corbiere, M.A. 2013. How do /ni/, /taa/, /se/ and /shin/ alter meanings of Nishinaabekidwinan? In Corbiere, A.O., M.A. Corbiere, D. McGregor and C. Migwans (eds.). Anishinaabewin Niiwin. M'Chigeeng: Ojibwe Cultural Foundation. Pp. 131-140.

Coulthard, G.S. 2014. Red skin, white masks: rejecting the colonial politics of recognition. Minneapolis: University of Minnesota Press.

Country, B., S. Wright, S. Suchet-Pearson, K. Lloyd, L. Burarrwanga, R. Ganambarr and J. Sweeney. 2016. Co-becoming Bawaka: towards a relational understanding of place/space. Progress in Human Geography 40(4): 455-475.

Cragoe, N.G. 2017. Following the green path: honor the Earth and presentations of Anishinaabe Indigeneity. Wicazo Sa Review 32(2): 46-70.

Daigle, M. 2016. Awawanenitakik: the spatial politics of recognition and relational geographies of Indigenous self-determination. The Canadian Geographer / Le Géographe Canadien 60(2): 259-269.

Davidson-Hunt, I. and F. Berkes. 2003. Learning as you journey: Anishinaabe perception of social-ecological environments and adaptive learning. Ecology and Society 8(1): 5.

Deloria, V.J. 2001. Power and place equal personality. In Deloria, V.J. and D. Wildcat (eds.). Power and place: Indian education in America. Golden, CO: Fulcrum Publishing.

Doerfler, J., N.J. Sinclair and K.H. Stark. 2013. Centering Anishinaabeg studies: understanding the world through stories. East Lansing, MI: Michigan State University Press.

Dokis, C. 2015. Where the rivers meet: pipelines, participatory resource management, and Aboriginal-state relations in the Northwest Territories. Vancouver, BC: UBC Press.

Dumont, J.O. 2015. What was never told. Chippewas of the Thames First Nation.

Enbridge Line 9B Reversal and Line 9 Capacity Expansion Project-Enbridge Inc. [accessed on 15 November 2018] https://www.enbridge.com/ECRAI.aspx

Fitz-Henry, E. 2017. Multiple temporalities and the nonhuman Other. Environmental Humanities 9(1): 1-17.

Foster, H. 2017. Another good thing: Ross River Dena Council v. Canada in the Yukon Court of Appeal: or: Indigenous title, presentism; in law and history, and a judge Begbie Puzzle revisited. University of British Columbia Law Review 50(2): 293-320.

Frantz, K. and R. Howitt. 2012. Geography for and with Indigenous peoples: Indigenous geographies as challenge and invitation. GeoJournal 77(6): 727-731.

Geniusz, W.M. 2009. Our knowledge is not primitive: decolonizing botanical Anishinaabe teachings. Syracuse, NY: Syracuse University Press.

Giniwgiizhig, H.F. 2013. An analysis of traditional Ojibwe civil Chief leadership. Ph.D. dissertation. Minneapolis, MN: University of Minnesota.

Goodin, R. 2009. Temporal justice. Journal of Social Policy 39(1): 1-16. 
Government of Canada. 1985. National Energy Board Act. [accessed 16 November 2018] https://lawslois.justice.gc.ca/eng/acts/N-7/

Government of Canada. 2018. Bill C-69 (42-1): An Act to Enact the Impact Assessment Act and the Canadian Energy Regulator Act, to amend the Navigation Protection Act and to make consequential amendments to other acts. Parliament of Canada. [accessed 15 November 2018] http://www.parl.ca/DocumentViewer/en/42-1/bill/C-69/third-reading

Grant, S. 2014. Securing tar sands circulation: risk, affect, and anticipating the Line 9 reversal. Environment and Planning D: Society and Space 32(6): 1019-1035.

Haluza-DeLay, R. and A. Carter. 2014. Joining up and scaling up: analyzing resistance to Canada's "dirty oil". In Bencze, L. and S. Alsop (eds.). Activist science and technology education. Dordrecht: Springer. Pp. 343-362.

Hatfield, S., E. Marino, K.P. Whyte, K.D. Dello and P.W. Mote. 2018. Indian time: time, seasonality, and culture in Traditional Ecological Knowledge of climate change. Ecological Processes 7(1): 25.

Hearne, J. 2017. We all stand side by side: an interview with Elizabeth LaPensée. Studies in American Indian Literatures 29(1): 27-37.

Heynen, N. and L. Van Sant. 2015. Political ecologies of activism and direct action politics. In Perreault, T. A., G. Bridge and J. McCarthy (eds.). The Routledge handbook of political ecology. London: Routledge. Pp. 169-178.

Horn-Miller, K. 2013. What does Indigenous participatory democracy look like? Kahnawa:ke's community decision making process. Review of Constitutional Studies 18(1): 111-133.

Horton, R.A. 2014. To our Anishinaabemowin teachers: we are listening. Rabble. http://rabble.ca/news/2014/02/to-our-anishinaabemowin-teachers-we-are-listening

Huebener, P. 2015. Timing Canada: the shifting politics of time in Canadian literary culture. Montreal: McGill-Queen's University Press.

Hunsberger, C. and S. Awasis. 2019. Energy justice and Canada's National Energy Board: a critical analysis of the Line 9 pipeline decision. Sustainability 11(3): 783-802.

Igreja, V. 2012. Multiple temporalities in Indigenous justice and healing practices in Mozambique. The International Journal of Transitional Justice 6(3): 404-422.

Iparraguirre, G. 2016. Time, temporality and cultural rhythmics: an anthropological case study. Time and Society 25(3): 613-633.

Irwin, L. 1997. Freedom, law, and prophecy: a brief history of Native American religious resistance. American Indian Quarterly 21(1): 35-55.

Jewell, E.M. 2018. Gimaadaasamin, we are accounting for the People: support for customary governance in Deshkan Ziibiing. Ph.D. dissertation. Victoria, BC: Royal Roads University.

Johnson, J., R. Howitt, G. Cajete, F. Berkes, R. Louis and A. Kliskey. 2016. Weaving Indigenous and sustainability sciences to diversify our methods. Sustainability Science 11(1): 1-11.

Kimmerer, R.W. 2003. Gathering moss: a natural and cultural history of mosses. Corvallis, OR: Oregon State University Press.

Kowal, E. 2015. Time, Indigeneity and white anti-racism in Australia. The Australian Journal of Anthropology 26(1): 94-111.

Kulchyski, P.K. 2013. Aboriginal rights are not human rights: in defence of Indigenous struggles. Winnipeg, MB: Arbeiter Ring Publishing.

LaDuke, W. 2015. The Thunderbirds versus the Black Snake: on Anishinaabe Akiing, an epic battle against oil pipelines is underway. Earth Island Journal 30(3): 44-48.

Larsen, S.C. and J.T. Johnson. 2012. In between worlds: place, experience, and research in Indigenous geography. Journal of Cultural Geography 29(1): 1-13.

Louis, R.P. 2007. Can you hear us now? Voices from the margin: using Indigenous methodologies in geographic research. Geographical Research 45(2): 130-139. 
Love, T. and E. Tilley. 2013. Temporal discourse and the news media representation of Indigenous-nonIndigenous relations: a case study from Aotearoa New Zealand. Media International Australia 149(1): 174-188.

McCreary, T. A. and R.A. Milligan. 2013. Pipelines, permits, and protests: Carrier Sekani encounters with the Enbridge Northern Gateway Project. Cultural Geographies 21(1): 115-129.

McGregor, D. 2013. Indigenous women, water justice and Zaagidowin (love). Canadian Woman Studies 30(2-3): 71-79.

MNCFN (Mississaugas of the New Credit First Nation). 2013. Written argument of the Mississaugas of the New Credit First Nation. NEB File OF-FAC-OIL-E101-2012-10 02, Document C3-11-2.

Middleton, B.R. 2015. Jahat Jatitotodom: toward an Indigenous political ecology. In Bryant, R. (ed.). The international handbook of political ecology. Northampton, MA: Edward Elgar. Pp. 561-576.

Miller, C. 2013. Every dream is a prophecy: rethinking revitalization - dreams, prophets, and routinized cultural evolution. In Doerfler, J., N.J. Sinclair and H.K. Stark (eds.). Centering Anishinaabeg studies: understanding the world through stories. East Lansing, MI: Michigan State University Press. Pp. 119132.

Nadasdy, P.E. 2008. Wildlife as renewable resource: competing conceptions of wildlife, time, and management in the Yukon. In Ferry, E.E. and M.E. Limbert (eds.). Timely assets: the politics of resources and their temporalities. Santa Fe: School for Advanced Research Press. Pp. 75-106.

Nelson, M.K. 2013. The hydromythology of the Anishinaabeg. In Doerfler, J., N.J. Sinclair and H.K. Stark (eds.). Centering Anishinaabeg studies: understanding the world through stories. East Lansing, MI: Michigan State University Press. Pp. 213-233.

Ogden, R. 2009. "Existing" Aboriginal rights in Section 35 of the Constitution Act, 1982. The Canadian Bar Review 88(0): 51-85.

Panelli, R. 2008. Social geographies: encounters with Indigenous and more-than-White/Anglo geographies. Progress in Human Geography 32(6): 801-811.

Pine, D.T. 2016. Ziisabaakodakaan: the place where sugar is made. Masters thesis. Toronto, ON: University of Toronto.

Porter, J. 2017. Northern Ontario First Nations take TransCanada to court over pipeline work. Thunder Bay, ON: CBC News.

Powell, D.E. 2015. The rainbow is our sovereignty: Rethinking the politics of energy on the Navajo Nation. Journal of Political Ecology 22(1): 53-78.

Richotte, K. 2013. Telling all of our stories: reorienting the legal and political events of the Anishinaabeg. In Doerfler, J., N.J. Sinclair and H.K. Stark (eds.). Centering Anishinaabeg studies: understanding the world through stories. East Lansing, MI: Michigan State University Press. Pp. 379-396.

Rifkin, M. 2017. Beyond settler time: temporal sovereignty and Indigenous self-determination. Durham, NC: Duke University Press.

Robbins, P. 2015. The trickster science. In Perreault, T.A., G. Bridge and J. McCarthy (eds.). The Routledge handbook of political ecology. London: Routledge. Pp. 89-101.

Scott, D.N. 2013. Situating Sarnia: "unimagined communities" in the new national energy debate. Journal of Environmental Law and Practice 25: 81-111.

Simpson, L.B. 2011. Dancing on our turtle's back: stories of Nishnaabeg re-creation, resurgence and a new emergence. Winnipeg, MB: Arbeiter Ring Publishing.

Simpson, L.B. 2017. As we have always done: Indigenous freedom through radical resistance. Minneapolis, MN: University of Minnesota Press.

Sparks, R. 2017. Ontario First Nations abandon request for emergency stop on TransCanada pipeline work. Toronto, ON: National Observer Media Group. 
Supreme Court of Canada. 2017. Chippewas of the Thames First Nation v. Enbridge Pipelines Inc. SCC Cases (Lexum). [accessed 15 November 2018] https://scc-csc.lexum.com/scc-csc/scccsc/en/item/16744/index.do

Sundberg, J. 2003. Conservation and democratization: constituting citizenship in the Maya Biosphere Reserve, Guatemala. Political Geography 22(7): 715-740.

Sundberg, J. 2014. Decolonizing posthumanist geographies. Cultural Geographies 21(1): 33-47.

The Expert Panel on the Modernization of the National Energy Board. 2017. Forward, together: enabling Canada's clean, safe, and secure energy future. Ottawa, ON: Natural Resources Canada.

Unist'ot'en Camp. 2017. Heal the people, heal the land. [accessed 12 March 2020] https://unistoten.camp

Weir, L. 2013. "Time immemorial" and Indigenous rights: a genealogy and three case studies (Calder, Van der Peet, Tsilhqot'in) from British Columbia. Journal of Historical Sociology 26(3): 383-411.

Whyte, K. 2018. Indigenous science (fiction) for the Anthropocene: ancestral dystopias and fantasies of climate crises. Environment and Planning E 1(1): 224-242.

Wilson, S. 2008. Research is ceremony: Indigenous research methods. Halifax, NS: Fernwood Publishing.

Yeh, E. and J. Brayn. 2015. Indigeneity. In Perreault, T.A., G. Bridge and J. McCarthy. (eds.). The Routledge handbook of political ecology. London: Routledge. Pp. 531-544. 